\title{
Prisons of Law and Brothels of Religion: William Blake's Christian Anarchism
}

\author{
Duane Williams \\ Liverpool Hope University
}

This chapter demonstrates how both anarchistic and religious tendencies are fused in William Blake's work. While acknowledging biographical and historical approaches to Blake scholarship, the methodological approach is foremost hermeneutical. Highlighting how Blake can be understood as a Christian anarchist by interpreting the significance of key beliefs and arguments found in his work, the chapter also explores Blake's opposition to both judicial and moral law, which underpins his questioning of the authority and rule of king and priest. The chapter consists of two sections. First it analyses Blake's complete mistrust of institutional state religion, along with its establishment of priests who, Blake maintained, cruelly bound and thus enslaved believers with moral law, then it examines Blake's view of Jesus as a transgressor of this law, through his unique insight concerning the mutual forgiveness of sins that places love and liberty above all else.

\section{Introduction}

It has been said of William Blake that he is an: 'Uncompromising supporter of freedom from all institutions, laws, and moral codes; he is a Christian anarchist.' However, while Blake scholarship is multifarious, very little appears to have been written on Blake in

I Victor, N. Paananen, William Blake, (New York: Twayne Publishing, I996), p. xiii.

How to cite this book chapter:

Williams, D. 20I8. Prisons of Law and Brothels of Religion: William Blake's Christian Anarchism. In: Christoyannopoulos, A. and Adams, M. S. (eds.) Essays in Anarchism and Religion: Volume II. Pp. 232-277. Stockholm: Stockholm University Press. DOI: https:/doi.org/Io.I6993/bas.h. License: CC-BY. 
direct relation to anarchism. Therefore, we might not immediately make a connection between the two. This said, where themes such as 'dissent', 'radicalism', 'revolution', and 'antinomianism' have preoccupied Blake scholars they have indirectly characterised some of the anarchistic elements of his thinking. Exceptions that focus explicitly on Blake and anarchism include the short book by Peter Marshall, William Blake: Visionary Anarchist, and an essay by Christopher Z. Hobson titled, 'Anarchism and William Blake's Idea of Jesus.' ${ }^{2}$ My aim in this essay is to show how Blake can be understood as a Christian anarchist. That Blake can be understood as a Christian anarchist is different from saying that he identified himself as one, and this is a subtle and important qualification that I will develop in the conclusion.

Before I begin it might be helpful to provide some explanatory notes on how I intend to approach the essay. While I incorporate some fairly well trodden areas in Blake studies, my intention is to gather them under one overarching theme in order to gain an all-round picture of how anarchistic and religious tendencies are fused in Blake's work. My aim is not to highlight potential problems with what I deem to be Blake's Christian anarchism. I appreciate that problems may arise in readers' minds, but my desire foremost is to expound and celebrate what I see as a significant, if speculative, facet of Blake's work while seeking to anticipate potential issues.

I will refer chiefly to Blake's writings, and occasionally to his visual art. Barring a few editorial symbols, I will also quote his writings without intervention as they are faithfully copied in David V. Erdman's, The Complete Poetry and Prose of William Blake. ${ }^{3}$ In terms of interpreting Blake's poems, although I am aware of the dramatic context of speeches some of them contain, I will nevertheless tend to attribute words directly to Blake. Although this might serve in simplifying the poems, I do it on the assumption

2 See Peter Marshall, William Blake: Visionary Anarchist, (London: Freedom Press, I988), and Christopher Z. Hobson, 'Anarchism and William Blake's Idea of Jesus', The Utopian, vol. I, 2000.

3 One of the anonymous reviewers of this essay said of Blake's frequent and significantly irregular punctuation and syntax: 'Anarchism is inscribed at the level of textuality, too, and Blake's singularity should stand.' 
that ultimately Blake is using figures to express his own views. I say this regarding what Blake calls 'mental deities' ${ }^{4}$ mindful that according to the journalist Henry Crabb Robinson (who knew him in later life) Blake maintained: 'that in asserting the actuality of spirits he was giving personality to ideas as Plato had done before.' 5 Or what Blake's friend, Frederick Tatham, called his 'peopled Thoughts. ${ }^{6}$ In places I will draw attention to the chronology of Blake's writings, but frequently I will overlook this because the meaning of the text will be my chief concern. ${ }^{7}$

This brings me to my methodological approach. Ideally I would include a biographical and historical perspective, exploring the different facets of religious dissent and political radicalism that arguably influenced Blake's thinking. But part of my reason for not doing so is that the extent to which Blake was influenced by or belonged to these movements is an endless source of speculation, and even questioned. ${ }^{8}$ While I acknowledge the significance of

4 William Blake, The Marriage of Heaven and Hell, Plate I I, The Complete Poetry and Prose of William Blake, Edited by David V. Erdman (New York: Anchor Books, I988), p. 38.

5 G. R. Bentley, Jr., Blake Records (Oxford: Clarendon Press, I969), p. 363.

${ }^{6}$ Richard Holmes, Blake's Songs of Innocence and Experience, (London: Tate Publishing, I992), p. 6.

7 I appreciate, however, that there are dangers here because it overlooks how a younger Blake was different from an older Blake. Nevertheless, I will do this with a consistency in mind regarding Blake's outlook.

8 See, for example, Keri Davies and David Worrall, 'Inconvenient Truths: Re-historicizing the Politics of Dissent and Antinomianism', and, 'Christ and the Bridal Bed: Eighteenth-Century Moravian Erotic Spirituality as a Possible Influence on Blake', in Re-Envisioning Blake, Edited by, Mark Crosby, Troy Patenaude, and Angus Whitehead (Basingstoke: Palgrave Macmillan, 20I2). Davies and Worrall question Blake's connection with Dissenter and Antinomian movements. Blake has often been linked through his mother to the Moravians who in turn have been interpreted as being Dissenters. But Davies and Worrall write: 'The Moravians saw themselves in no sense dissenters from, but, on the contrary, as a sister church of, the Church of England.' Davies and Worrall, 'Inconvenient Truths', p. 37. And furthermore that: 'The dissenting churches viewed the Moravian Brethren with hostility.' Davies and Worrall, 'Inconvenient Truths', p. 40. Atwood writes: 'In I749, the British Parliament officially recognized the Moravian Church as a legitimate ecclesiastical body (rather than a dissenting group)' Atwood, 'Christ and the Bridal Bed', p. I62. But while the Moravians viewed themselves as not being 
the biographical and historical approaches to Blake scholarship, my methodological approach is foremost hermeneutical. This is partly down to space, but also as a philosopher and theologian I confess to being more comfortable in this area (and more interested if I am completely honest) whereas with the biographical and historical I am more dependent on the scholarship of others. ${ }^{9}$ This said, where necessary I will incorporate some of this scholarship. Concerning the hermeneutical, my main task is to highlight how Blake can be understood as a Christian anarchist by interpreting the significance of key beliefs and arguments found in his work. I will do this by exploring how Blake was opposed to both judicial and moral law thus questioning the authority and rule of king and priest. However, given the theme of this essay I will tend to focus more on the moral and priestly angle. To this end my essay will consist of two sections. I will begin by exploring Blake's complete mistrust of institutional state religion, along with its establishment of priests who, he maintained, cruelly bound and thus enslaved

Dissenters, Davies and Worrall claim that they were forced to register their churches as dissenting meeting-houses. With the above in mind I wish to avoid what Davies and Worrall call the critical and biographical commonplace that Blake was a Dissenter, although I keep an open-mind that he still may have been one either through influence or allegiance. See Davies and Worrall, 'Inconvenient Truths', p. 40. Highlighting key texts that have identified Blake as a Dissenter and following what they take to be sound evidence that opposes this, Davies and Worrall write: 'The easy labelling of William Blake as a dissenter has next to no validity.' Davies and Worrall, 'Inconvenient Truths', p. 44. But of course given the nature of academia, at some point in the future there may be further evidence unearthed that seeks to argue there is validity. Until that time, Davies and Worrall write: 'Blake the Dissenter can now only ever be someone else's unmarked grave in Bunhill Fields. It certainly is not that of William Blake, I757-I 827, late of Fountain Court.' Davies and Worrall, 'Inconvenient Truths', p. 47.

9 I am also mindful of a point made by Davies and Worrall that says 'the current character of Blake studies is generally historicist.' Davies and Worrall, 'Inconvenient Truths', p. 3 I. This they add, drawing on conclusions made by the Research Assessment Exercise of 2008, is the currently dominant approach to all research in English departments regarding orientation and method. Davies and Worrall, 'Inconvenient Truths', p. 3I. I do not wish to add to this dominant historicist criticism, nor am I qualified to do so. Also I am not from an English department, but a department of Theology, Philosophy, and Religious Studies. 
believers with moral law. And in the next section I will examine Blake's view of Jesus as a transgressor of this law, through the latter's unique insight concerning the mutual forgiveness of sins that places love and liberty above all else.

We can view these two sections as each referring to what are for Blake different interpretations of religion, namely, a false one and a true one. Briefly, for Blake, false religion is that which preaches vengeance for sin based on judicial and moral laws of good and evil, which are universally applied to all individuals thereby circumscribing their freedom and authorizing punishment for their transgressions. For Blake, general prohibitive laws like the Ten Commandments are oppressive and inherently unjust. In contrast, true religion subverts such cruel systems of law through mutual forgiveness that counteracts sin and engenders a universal humanity or divine body living as members of One Man - Jesus Christ.

Finally, I would just like to say a few words about my own approach to the concepts of 'anarchism' and 'religion.' If I was to think of one word that encapsulated the essence of both these subjects it would be 'liberty.' It might be argued that anarchy and religion both offer freedom in their differing contexts from those things that rule us, be that monarchs, government, laws, desires, suffering, ignorance, and so forth. And in some cases the concepts of anarchism and religion are arguably fused through a figure concerned with one of the topics listed above, Lao-Tzu and government, for example. Likewise, in this essay anarchism and religion will be argued to come together through Blake's interpretation of Jesus as a radical visionary and religious transgressor.

\section{Institutionalised Religion and Priesthood}

In relation to Blake, reference is often made to the publisher Joseph Johnson who had been associated with a network of religious dissenters and political radicals in London since the I 760 s. Johnson had agreed to publish a poem by Blake titled, The French

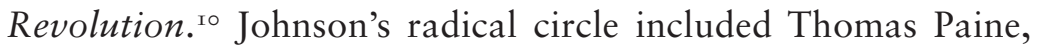

זo This was in seven books, but either due to government pressure or because of the foretold inaccuracy of the work the publication did not 
Mary Wollstonecraft, William Godwin and Joseph Priestley. Some Blake scholars and biographers have argued that Blake attended weekly dinners above Johnson's bookshop, where he may have met and befriended such figures. Others, however, have argued that according to the evidence Blake probably only ever attended one of these dinners. While it is tempting to place Blake among the circle around Johnson and to assume he would be at home there, Peter Ackroyd notes insightfully that Blake was quite different to them in many respects, especially when it came to views on religion. ${ }^{\text {II }}$ Alexander Gilchrist says: 'Himself [Blake] a heretic among the orthodox, here among the infidels he was a saint and staunchly defended Christianity - the spirit of it - against these strangely assorted disputants.' ${ }^{\mathrm{I} 2}$ Frederick Tatham, Blake's friend in later life, is also quoted to have said: 'In one of their conversations, Paine said that religion was a law $\&$ a tye to all able minds. Blake on the other hand said what he was always asserting, that the religion of Jesus, was a perfect law of Liberty.' ${ }^{\text {'3 }}$ For me Tatham's recollection, accurate or not, serves in drawing our attention to a crucial distinction in Blake's thinking. For when it came to institutionalised religion, priesthood, and moral law, Blake would have no doubt agreed with Thomas Paine's sentiments. But regarding what Blake saw as the true religion of Jesus he would certainly have disagreed with Paine. The rest of this essay will consider this distinction. ${ }^{\mathrm{I}}$

To a certain extent then Blake would have accepted Paine's view that 'religion was a law and a tye to all able minds', but to

happen. All that remains of the poem is the page proofs of the first book. The remaining six are lost.

ir Peter Ackroyd, Blake (London: Sinclair-Stevenson, I995), p. I 59. Ackroyd speculates that it would be an error to see Blake as a part of Johnson's group dining above the shop, and that they probably only saw him as a journeyman engraver with eccentric views.

I2 Alexander Gilchrist, Life of William Blake, ed. Ruthven Todd (London and New York, I942), p. 94.

I3 Bentley, Blake Records, pp. 530-I.

${ }^{14}$ Regarding his thoughts on Paine, it is worth reading Blake's 'Annotations to An Apology for the Bible, by R. Watson, Bishop of Landaff. London, I797', in Erdman, The Complete Poetry and Prose of William Blake, pp. 6II-20. 
Blake's thinking it was only a corrupted and perverted form of religion that did this. It was institutionalised, state religion, comprising (in a Christian context) the established churches and their priests who bound and restricted believers with moral law, just as the crown and government did with judicial law. We can perhaps draw attention here to Jesus' words when he says of the scribes and Pharisees: '. . . they bind heavy burdens and grievous to be borne, and lay them on men's shoulders.' ${ }^{5}$ Whereas, in contrast, Jesus invites those who feel the burden of their sins: 'Take my yoke upon you, and learn of me; ... for my yoke is easy, and my burden is light.' ${ }^{16}$

In Blake's poem, 'The Chimney Sweeper', one of his Songs of Experience that appeared in I794, the sweep is asked of the whereabouts of his parents? His reply is that they are in the church praying: 'And are gone to praise God \& his Priest \& King / Who make up a heaven of our misery.' ${ }^{\prime 7}$ Blake's religious, social, and political sentiments are all captured in his well-known poem titled, 'London', again from Songs of Experience. This poem also connects the chimney sweeper and Church through the lines: 'How the Chimney-sweeper's cry / Every blackning Church appalls.' ${ }^{\text {I8 }}$ Alfred Kazin argued that getting the soot out of the church was an impossible task for the boy in the poem, and asserts how the church is black with 'dogma and punitive zeal' and made all the blacker by the chimney sweeper's suffering. And turning to the word 'appalls' he observes how the church is not appalled by the plight of the boy and this makes the church appalling. ${ }^{19}$

Blake held the resolutely independent position that questioned the necessity of going through the institution of the Church to get to God. He writes: 'Henceforth every man may converse with God

\footnotetext{
${ }_{15}$ Mt 23: 4. KJV.

${ }^{16} \mathrm{Mt}$ I I: 29-30. KJV.

${ }^{17}$ Blake, 'The Chimney Sweeper', Songs of Experience, in Erdman, The Complete Poetry and Prose of William Blake, p. 23.

I8 Blake, 'London', Songs of Experience, in Erdman, The Complete Poetry and Prose of William Blake, p. 27.

19 Alfred Kazin, The Portable Blake (Harmondsworth: Penguin Books, I946), pp. I4-I 5 .
} 
\& be a King \& Priest in his own house. ${ }^{20}$ John Beer links Blake's assertion to: 'Theophilus Evan's millenarian statement that once man regains the perfection of Adam, the Law will be 'writ in every Man's heart, so that . . every Man should be Priest unto himself'.'2I There are perhaps also echoes of Jesus' exchange with the woman of Samaria at the well, where Jesus says: 'But the hour cometh, and now is, when the true worshippers shall worship the Father in spirit and truth: for the Father seeketh such to worship him.'22

Much of Blake's writing condemns what he perceives to be the false institutional religion, and champions in turn what is for him true religion. A perfect example of this distinction is found in the following lines from Blake's work, The Marriage of Heaven and Hell:

The ancient Poets animated all sensible objects with Gods or Geniuses, calling them by the names and adorning them with the properties of woods, rivers, mountains, lakes, cities, nations, and whatever their enlarged $\&$ numerous senses could perceive. And particularly they studied the genius of each city \& country. placing it under its mental deity; Till a system was formed, which some took advantage of \& enslav'd the vulgar by attempting to realize or abstract the mental deities from their objects: thus began Priesthood, Choosing forms of worship from poetic tales. And at length they pronounced that the Gods had ordered such things. Thus men forgot that All deities reside in the human breast ${ }^{23}$

${ }^{20}$ Erdman, 'Annotations to An Apology for the Bible, by R. Watson, Bishop of Landaff. London, I797', The Complete Poetry and Prose of William Blake, p. 6I 5 .

${ }^{21}$ John Beer, William Blake: A Literary Life (Basingstoke: Palgrave Macmillan, 2007), p. 22.

22 Jn 4: 23 , KJV.

${ }^{23}$ Blake, The Marriage of Heaven and Hell, Plate II, in Erdman, The Complete Poetry and Prose of William Blake, p. 38. S. Foster Damon links the last line to Lavater's $398^{\text {th }}$ Aphorism: 'Let none turn over books or roam the stars in quest of God, who sees him not in man.' S. Foster Damon, A Blake Dictionary (Hanover and London: University Press of New England, I988), p. 322. Also note the similarity of Blake's passage with Coleridge's lines from 'The Piccolomini': 'The intelligible forms of ancient poets, / The fair humanities of old religion, / The power, the Beauty, and the Majesty / That had their haunts in dale or piny mountain, / Or 
Blake confirms this last point in the same work when he later writes: 'God only Acts \& Is, in existing beings or Men.' ${ }^{24}$ And then again: 'The worship of God is. Honouring his gifts in other men, each according to his genius. and loving the greatest men best, those who envy or calumniate great men hate God, for there is no other God.'25 As will become more significant as we proceed, this tells us that for Blake: 'God is not in some unknown world elsewhere. ${ }^{26}$ Blake referred to God understood in this metaphysical way as, 'Nobodaddy', which S. Foster Damon translates as meaning, 'nobody's daddy.' ${ }^{27}$ Although I wonder if it might equally mean, 'no body daddy' in the sense of a god with no body, or 'nobody daddy' in the apophatic sense of a god that is nothing. In his poem 'To Nobodaddy', Blake writes of what he (as we will come to see) deems to be a false god:

Why art thou silent $\&$ invisible

Father of Jealousy

Why dost thou hide thyself in clouds

From every searching Eye

Why darkness \& obscurity

In all thy words \& laws

That none dare eat the fruit but from

The wily serpents jaws ${ }^{28}$

Damon writes: 'The abstract God of the Anglican Prayer Book, "without passion or parts," was for Blake a mere logical abstraction without significance. ${ }^{29}$ Here Blake accords with Johann Kaspar Lavater, who in one of his Aphorisms on Man writes: 'He, who adores an impersonal God, has none; and, without guide

forest, by slow stream, or pebbly spring. / Or chasms and watery depths.'

Thomas Bulfinch, Bulfinch's Mythology (London: Spring Books, I967), p. 5 .

${ }^{24}$ Blake, The Marriage of Heaven and Hell, Plate I6, in Erdman, The Complete Poetry and Prose of William Blake, p. 40.

25 Blake, The Marriage of Heaven and Hell, Plate 22, in Erdman, The Complete Poetry and Prose of William Blake, p. 43.

${ }^{26}$ Paananen, William Blake, p. 54.

27 Damon, A Blake Dictionary, p. 301.

${ }_{28}$ Blake, 'To Nobodaddy', in Erdman, The Complete Poetry and Prose of William Blake, p. 47I.

29 Damon, A Blake Dictionary, p. I 59. 
or rudder, launches on an immense abyss that first absorbs his powers, and next himself.' ${ }^{\circ}$ In his annotation to this aphorism, Blake responds with: 'Most superlatively beautiful \& most affectionately Holy \& pure would to God that all men would consider it.' ${ }^{3}$ I

Blake loathed the mental and corporeal cruelties enacted by the Church in the name of this systematized and abstracted God, and he set out to denounce them. An example of the Church's cruelty according to Blake is found in his poem, 'A Little Boy Lost' from Songs of Experience. The boy we can assume is lost in more ways than one, but especially perhaps because found and seized by the Church. In the poem the boy asserts:

Nought loves another as itself

Nor venerates another so.

Nor is it possible to Thought

A greater than itself to know: ${ }^{32}$

Here the boy is demanding the right to assert his own thoughts and desires. ${ }^{33}$ This, I believe, also connects with Blake's dislike of an impersonal God that supersedes and possibly absorbs our own identity. For Blake, the personal or the human is not to be overlooked in the name of metaphysical abstraction. The boy in the poem then asks his father, how can I love you or any of my brothers more than this? However, a priest overhears the child and seizes him with 'trembling zeal' by the hair, to which Blake with a stinging criticism designed to expose both the action of the priest and the inaction of those standing by, sarcastically adds: 'And all admir'd the Priestly care.'34 Meanwhile the weeping child cannot be heard and twice Blake says that the parents weep in vain, suggesting the overriding power and influence of

${ }^{\circ}$ Lavater, Aphorism 552, in Erdman, The Complete Poetry and Prose of William Blake, p. 596.

${ }^{31}$ Blake, 'Annotations to Lavater', in Erdman, The Complete Poetry and Prose of William Blake, p. 596.

32 Blake, 'A Little Boy Lost', Songs of Experience, in Erdman, The Complete Poetry and Prose of William Blake, p. 28.

33 Kazin, The Portable Blake, p. 4I.

34 Blake, 'A Little Boy Lost', Songs of Experience, in Erdman, The Complete Poetry and Prose of William Blake, p. 28. 
the Church. Following this the boy is stripped to his little shirt and bound in an iron chain. The final verse says that he is then burned where many have been burned before, and closes with the line: 'Are such things done on Albions shore.' 35 The implication is that on a subtle level such things are done by priests, as well as by parents, teachers, politicians, and monarchs. All in all, and capturing the essence I think of Blake's thinking, the boy is guilty of wanting to be autonomously himself and is in turn punished for it. Here Blake is deliberately inverting what is commonly taken to be the truth, this being that all our problems come as a result of defying the divine laws, whereas on the contrary: 'Blake believed many of the ills of the world to result from a loss of imagination and an unwillingness to cultivate human energies in freedom. ${ }^{36}$

Blake loathed the notion of universal laws applicable to all. Such laws ignore what Blake took to be fundamentally true that we are all different. A difference crushed under the rule of One God, One King, and One Law. With reference to universal law, Damon tells us that to Blake the Ten Commandments were: 'Negative generalizations drawn up regardless of the individual ... Blake was emphatic that human happiness should not be sacrificed to the traditional rules, the individual should always be considered first.' ${ }^{\prime} 7$ Hence Blake ends The Marriage of Heaven and Hell with the line: 'One Law for the Lion \& Ox is Oppression'38 Elsewhere, Bromion (characterising reason) asks: 'And is there not one law for both the lion and the ox?' ${ }_{9}$ While similarly Tiriel (representing the body and the decay of materialism) asks: 'Why is one law given to the lion $\&$ the patient ox?'40 After this particular

35 Blake, 'A Little Boy Lost', Songs of Experience, in Erdman, The Complete Poetry and Prose of William Blake, p. 29.

${ }^{36}$ Beer, William Blake: A Literary Life, p. 97.

37 Damon, A Blake Dictionary, p. 90.

${ }^{38}$ Blake, The Marriage of Heaven and Hell, Plate 24, in Erdman, The Complete Poetry and Prose of William Blake, p. 44.

39 Blake, Visions of the Daughters of Albion, 4: 22, in Erdman, The Complete Poetry and Prose of William Blake, p. 48.

4० Blake, Tiriel, viii: Io, in Erdman, The Complete Poetry and Prose of William Blake, p. 285. 
line Blake had written before deletion: 'Dost thou not see that men cannot be formed all alike.'4r

This I would argue is not so much a question mark against equality, but against the One Law that judges us to be equal before it. As metaphors for types of people the lion and ox are indeed different, but their equality should stand in being equally free to be what it is they are. Where we do not have equal ways, we should have equal rights to those ways. Blake advocated liberty, equality, and fraternity, but he did not advocate uniformity. Marshall argues: 'He felt that no law could cover the multitude of individual acts and is thereby inherently unjust.' ${ }^{42}$

Blake often refers to childhood play in his poems and paintings to depict the liberty and joy that rules and laws suppress. ${ }^{43}$ This might also be influenced by Jesus telling his disciples that unless they are converted and become like little children they will never enter the kingdom of heaven, and that of such is the kingdom of heaven. ${ }^{44}$ In his poem, 'The Garden of Love', again from Songs of Experience, Blake tells us that he went to the garden of love and sees that a chapel now stands where he used to play on the green. The immediate indication appears to be that the chapel puts an end to love and play. The poem continues:

And the gates of this Chapel were shut, And Thou shalt not. writ over the door; So I turn'd to the Garden of Love, That so many sweet flowers bore.

And I saw it was filled with graves, And tomb-stones where flowers should be:

${ }^{4}$ Blake, Tiriel, viii: Io. Note that the deleted line is still printed in, Geoffrey Keynes, The Complete Writings of William Blake (London: Oxford University Press, I966), p. I09.

${ }_{42}$ Marshall, William Blake: Visionary Anarchist, p. 42.

${ }_{43}$ See, for example, 'The Echoing Green', 'Laughing Song', and 'Nurse's Song' in Songs of Innocence, and 'The School Boy' in Songs of Experience.

${ }^{44}$ Mt I 8: 3; 19: I4, KJV. 
And Priests in black gowns, were walking their rounds, And binding with briars, my joys $\&$ desires. ${ }^{45}$

In the Gospel of John, Jesus says that he will destroy the temple and raise it up in three days. The Jews then ask how he can do this when the temple took forty-six years to build. But as we know Jesus is speaking in this instance of the temple of his body. ${ }^{46}$ Blake may be making a similar analogy with reference to the chapel. The gates of the chapel, our body, have been shut by religious prohibition that cruelly demands 'thou shalt not.' 47 Elsewhere and with allusions perhaps to Plato's cave allegory, Blake famously writes: 'If the doors of perception were cleansed every thing would appear to man as it is: infinite. For man has closed himself up, till he sees all things thro' narrow chinks of his cavern.' ${ }^{48}$ The 'doors of perception' refer to the five senses, which Blake understood to be: 'The chief inlets of Soul in this age.'49 Being closed up, everything appears finite and corrupt instead of infinite and holy. The cleansing of the doors of perception, says Blake, will come to pass by an improvement of sensual enjoyment. But as we have heard in the Garden of Love, Blake tells us that priests in black gowns are binding with briars his joys and desires. ${ }^{\circ}$ Referring elsewhere to joys, Blake asserts: 'As the caterpillar chooses the fairest leaves

45 Blake, 'The Garden of Love', Songs of Experience, in Erdman, The Complete Poetry and Prose of William Blake, p. 26.

${ }^{6}$ Jn 2:I9-2I, KJV.

47 Incidentally, Emanuel Swedenborg is said to have had a vision where he saw a magnificent temple with the words Nunc Licet written over the doorway. This translates as, 'now it is permitted'. For Swedenborg this meant 'Now it is permitted to enter intellectually into the mysteries of faith.'

$4^{8}$ Blake, The Marriage of Heaven and Hell, Plate I4, in Erdman, The Complete Poetry and Prose of William Blake, p. 39.

49 See, Blake, The Marriage of Heaven and Hell, Plate 4.

5० A briar refers to the pipe made of 'tree heath' that many priests of the time smoked. It might moreover refer by association to the rope-like smoke of the pipe. Briar is also the name of a wild thorny rose, which could also imply the crown of thorns worn by Jesus as a cruel means of torture. 
to lay her eggs on, so the priest lays his curse on the fairest joys. ${ }^{{ }^{1}}$ While with regard to desire he says: 'Those who restrain desire do so because theirs is weak enough to be restrained; and the restrainer or reason usurps its place $\&$ governs the unwilling. ${ }^{52}$ And in what on the surface appears to be one of his most shocking statements, he argues: 'Sooner murder an infant in its cradle than nurse unacted desires.' ${ }^{3}$ Blake also writes:

${ }^{51}$ Blake, The Marriage of Heaven and Hell, Plate 9, in Erdman, The Complete Poetry and Prose of William Blake, p. 37. He uses a similar image in his poem 'The Human Abstract', when he says: 'And the Catterpiller and Fly, / Feed on the Mystery.' Blake, Songs of Experience, in Erdman, The Complete Poetry and Prose of William Blake, p. 27.

52 Blake, The Marriage of Heaven and Hell, Plate 5, in Erdman, The Complete Poetry and Prose of William Blake, p. 34. Similarly Friedrich Nietzsche argued that the vices of some grow lazy, and they call that virtue. He adds: 'There are others who are like household clocks wound up; they repeat their tick-tock and want people to call tick-tock - virtue. And again, there are those who hold it a virtue to say: 'Virtue is necessary'; but fundamentally they believe only that the police are necessary.' Friedrich Nietzsche, Thus Spoke Zarathustra (London: Penguin, I96I), translated by, R. J. Hollingdale, pp. i 8 -i I 9.

53 Blake, The Marriage of Heaven and Hell, Plate ro, in Erdman, The Complete Poetry and Prose of William Blake, p. 38. This proverb has been the subject of much debate. I have always read it in the most shocking way to mean that it is far worse to not act on desires than it is to murder an infant in a cradle. But it is probably more subtle than this. Marshall says of this proverb: 'He means that repressed desires can make a person permanently cruel and destructive.' Marshall, William Blake: Visionary Anarchist, p. 48. It would seem therefore that it is better to murder the infant than nurse the person that would result from unacted desires. Similarly Beer writes of the proverb: 'This has attracted criticism from some critics, who take it as an injunction to follow one's desires however inhuman and cruelly murderous they may prove. But ... the logic needs to be read backwards rather than forwards. Acted desires are being compared to infants reared in proper freedom. It will be impossible for such desires to be inhuman or murderous, because they will by their very nature be the expression of a freedom which is fully human, embodying a full vision of human potentiality. It is unacted desires that are likely to fester, and which will then resemble children whose development has been thwarted by ill usage.' Beer, William Blake: A Literary Life, pp. 59-60. Thus it is better to murder in the cradle what would otherwise become unacted desires nursed. 
Let the Priests of the Raven of dawn, no longer, in deadly black, with hoarse note curse the sons of joy. Nor his accepted brethren, whom, tyrant, he calls free; lay the bound or build the roof. Nor pale religious letchery call that virginity, that wishes but acts not! ${ }^{54}$

Similar in some respects to the poem 'The Garden of Love' is a poem from Blake's notebook, commonly called, 'The Chapel of Gold':

I saw a chapel all of gold

That none did dare to enter in

And many weeping stood without

Weeping, mourning, worshipping

I saw a serpent rise between

The white pillars of the door

And he forcd \& forcd \& forcd

Down the golden hinges tore

And along the pavement sweet

Set with pearls \& rubies bright

All his slimy length he drew

Till upon the altar white

Vomiting his poison out

On the bread $\&$ on the wine

So I turnd into a sty

And laid me down among the swine ${ }^{55}$

Beer says of this poem: 'The very chapels in which abstinence was preached were caricatures of the bodily organ of sexual desire that had been made secret, and their adherents reaped a cruel crop. ${ }^{56}$ Typically in Blake's poems, the serpent represents the priest. I believe the poem evinces what the Church had reduced sex to. The serpent is penis and priest. The chapel is vagina and church:

${ }_{54}$ Blake, The Marriage of Heaven and Hell, Plate 27, in Erdman, The Complete Poetry and Prose of William Blake, p. 45.

55 Blake, 'The Chapel of Gold', in Erdman, The Complete Poetry and Prose of William Blake, pp. 467-8.

${ }^{56}$ Beer, William Blake: A Literary Life, p. 67. 
'Is it a symbol of priesthood polluting the most sacred things of life?'s7 Perhaps serving to confirm this and again connecting the chapel with the body, Blake also produced a pencil sketch titled, 'The Golden Chapel' depicting a woman with a gothic chapel for a vulva..$^{5}$ In a fragment from his notebook titled, 'Merlin's Prophecy', Blake says:

The harvest shall flourish in wintry weather

When two virginities meet together

The King \& the Priest must be tied in a tether

Before two virgins can meet together ${ }^{59}$

Where sexual continence is encouraged by the Church in the forms of complete sexual abstinence and the prohibition of extra-marital sex, it creates a defiled perception of sex as impure and sinful. Thus licentiousness and adultery come into being as debauched negatives, where before they were simply joyfully natural sex, namely, 'the garden of love' that bears so many sweet flowers. Blake, however, is not writing erotica. He is not seeing sex as something filthy and offensive and used therefore to defy social convention. Rather he is being open and sincere about something natural, and thereby opposing the anomalous restraint of desire, the ashamed need for surreptitiousness, the general fear of living, and the warped character that follows such forsaken self-deceit. ${ }^{60}$ Perceptively Kazin said of Blake that he was able to foresee:

The danger that is exactly present in our modern eroticism, which has the same relation to the failure of love that totalitarian solutions have to the failure of society. When we compare Blake with an artist like D. H. Lawrence, or an oratorical rebel like Henry Miller, we can see how much the obsessiveness, the cringing over-emphasis on sex in the most advanced modern writing is

57 S. Foster Damon, William Blake: His Philosophy and Symbols (Whitefish, Montana: Kessinger Publishing, 2006), p. 287. Damon adds that the sty is a cleaner place than the polluted temple.

${ }^{8}$ See from Vala, or the Four Zoas, 'The Golden Chapel', pencil, c. I797.

59 Blake, 'Merlin's Prophecy', in Erdman, The Complete Poetry and Prose of William Blake, p. 473.

${ }^{60}$ Kazin, The Portable Blake, p. 37. 
due to the inability of these writers to treat sex naturally in the whole frame of the human organization. As the dirty story pays homage to puritanism, so our modern eroticism wearily proclaims that the part which has been dislodged from the whole shall now be the key to experience. The limitations of eroticism have exactly the same character, in life and in art: it divorces sex from human culture. ${ }^{61}$

Concerning the negative views of sex that Blake felt the Church had created and the consequences of this, he tells us that just as Prisons are built with stones of Law so Brothels are built with bricks of Religion. ${ }^{62}$ This appears to argue that we only have prisons because of law, and only have brothels because of religion. Or as Paananen rather neatly puts it: 'For Blake the institutionalized moral prohibition in fact creates the vice that it condemns.' ${ }^{63}$ Marshall likewise says that Blake understood: 'Laws require prisons to enforce them as much as repressive morality creates the need for prostitutes. ${ }^{64}$ But in Blake's time the law did more than build prisons. It also built the gallows that could even be used to hang children.

Damon notes that Blake's proverb: 'Prisons are built with stones of Law, Brothels with bricks of Religion', must have been inspired by Paul's words: 'By the law is the knowledge of sin.' 65 If so Blake is, it would seem, applying his own twist to Paul. For when Paul writes: 'Therefore by the deeds of the law there shall no flesh be justified in his sight: for by the law is the knowledge of $\sin ^{\prime 66}$, he means that our obedience to the law may justify us in the eyes of ourselves and other people, but not in the eyes of God

61 Kazin, The Portable Blake, p. 38.

${ }_{62}$ See Blake, The Marriage of Heaven and Hell, Plate 8, in Erdman, The Complete Poetry and Prose of William Blake, p. 36.

63 Paananen, William Blake, p. $5 \mathrm{I}$.

${ }^{64}$ Marshall, William Blake: Visionary Anarchist, p. 42.

${ }_{65}$ Rom 3: 20, KJV. Damon adds that upon this passage grew one of the Gnostic heresies: 'Epiphanes . . . wrote a book On Justice . . . asserting . . . that the law, by introducing the distinction of meum and tuum, was the real author of the sin of theft and adultery.' (Mansel's Gnostic Heresies, VIII). Quoted from, Damon, William Blake: His Philosophy and Symbols, p. 320. Note that 'meum' and 'tuum' translate roughly as 'mine' and 'yours'.

${ }^{66}$ Rom 3: 20, KJV. 
before whom we are always guilty owing to the universal corruption in our nature. We are thus unlike Adam in his innocence or Christ whose works were perfect, because we are sinful. Thus our obedience to the law is always imperfect in God's eyes despite any justification by our own works. ${ }^{67}$ And so to say, 'by the law is the knowledge of sin', means for Paul that the very existence of the law lets us know we are sinners. If Blake was inspired by Paul's line, his aim may have been to take its conclusion and apply to it an opposite logic so as to say no law, no $\sin .^{68}$ This is because for Blake it is only the law itself that makes us sinners. Thus Marshall argues: 'It is law which alone defines a crime, invites people to commit it, and promises dire punishment.' ${ }^{69}$ The gist here is that for Blake law is not the cure for social and moral problems, but the main reason behind those problems. ${ }^{70}$

In some respects Blake was opposed to the notion of Sin, which he took to be a false infringement based on a manufactured code of morality designed to punish people for following their natural energies. However, as will become clear, Blake also realized that without Sin there could be no forgiveness. We might be justified in arguing that if there was no concept of Sin to begin with then there would be no need for forgiveness. Nevertheless there is a concept of Sin, which, as we shall see, forgiveness serves to counteract. This concept of Sin was important to Blake because if one is pure they cannot taste the sweets of the forgiveness of sins and if holy cannot behold the tears of love. ${ }^{71}$ With reference to Sin Blake writes: 'Satan thinks that Sin is displeasing to God he ought to know that Nothing is displeasing to God but Unbelief \& Eating

${ }^{67}$ My thoughts on Paul are guided here by Matthew Henry's Concise Commentaries, and John Gill's Exposition of the Entire Bible.

${ }^{68}$ In a related way Nietzsche writes: 'No morality has any value in itself.' Nietzsche, Twilight of the Idols, (London: Penguin, I968), Translated by, R. J. Hollingdale, p. Ioo. While elsewhere he similarly writes: 'There are no moral phenomena at all, only a moral interpretation of phenomena.' Nietzsche, Beyond Good and Evil, (London: Penguin, I973), Translated by, R. J. Hollingdale, p. 96.

69 Marshall, William Blake: Visionary Anarchist, p. 42.

70 Marshall, William Blake: Visionary Anarchist, p. 42.

${ }^{7}$ See, for example, Blake, Jerusalem, Plate 60, in Erdman, The Complete Poetry and Prose of William Blake, p. 2 I I. 
of the Tree of Knowledge of Good and Evil. ${ }^{72}$ We will explore why for Blake eating of the tree of the knowledge of Good and Evil is so significant in due course, but suffice to say that for Blake this is why there is a concept of Sin that demands forgiveness in the first place.

Regarding the 'natural energies' mentioned earlier that we are punished for following, Blake writes: 'Energy is the only life and is from the Body and Reason is the bound or outward circumference of Energy. Energy is Eternal Delight. ${ }^{73}$ While Blake lived in a time that called itself, 'The Age of Reason', he himself was more inclined to live in an 'Age of Imagination', 'Age of Inspiration' or 'Age of Energy.' Reason, for Blake, was represented by his god, Urizen. The name is said by many to be a pun for 'Your Reason',

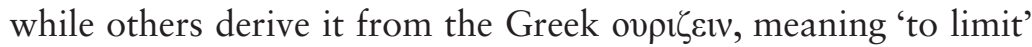
which is the root of the English 'horizon.' It could of course mean both for the point would appear to be that as a horizon your reason sets limits and bounds to your energy. For Blake, the typical depiction of Urizen is as an old man with a white beard, and we are perhaps meant to identify him with the, 'isolated paternal deity of traditional Christian iconography. ${ }^{74}$ Setting bounds to our energies he is the contrary to imagination, or Blake's god, Urthona. Urizen is the avenging god of punitive law. He is also known as an architect and uses a compass to draw his circumscribing lines and boundaries. ${ }^{75}$ Blake might be influenced here by Milton, who says of the Creator that he: 'Took the Golden Compasses, prepared / In God's eternal store, to circumscribe / This Universe, and all created things. ${ }^{76}$ In his note-book of $1808-\mathrm{I}$, Blake writes in the

${ }^{72}$ Blake, A Vision of the Last Judgment, in Erdman, The Complete Poetry and Prose of William Blake, p. 564.

73 Blake, The Marriage of Heaven and Hell, Plate 4, in Erdman, The Complete Poetry and Prose of William Blake, p. 34 .

74 Robert Ryan, 'Blake and Religion', The Cambridge Companion to William Blake (Cambridge: Cambridge University Press, 2003), p. I 56.

75 Hence Blake's reference to the brethren of priests who 'lay the bound or build the roof' that was quoted earlier from The Marriage of Heaven and Hell. See Blake, The Marriage of Heaven and Hell, Plate 27, in Erdman, The Complete Poetry and Prose of William Blake, p. 45.

${ }^{6}$ John Milton, Paradise Lost, vii, 225-7, quoted from, The Annotated Milton: Complete English Poems, (Ed.), Burton Raffel, (New York: Bantam Books, I999), p. 35 I. 
following lines titled, 'To God': 'If you have formd a Circle to go into / Go into it yourself \& see how you would do' 77

Blake's most vehement attack on institutionalised religion and its view of sexuality is perhaps found in his poem, Visions of the Daughters of Albion. Robert Ryan says of the poem:

Oothoon, the victim of rape, having been scorned by the rapist and rejected by the man who once loved her, delivers a searing indictment of the entire moral system in which she has been trapped, concluding with a bold advocacy of free love. In lines that still have power to shock, she speaks of masturbatory acts and asks, "Are not these the places of religion? the rewards of continence? / The self enjoyings of self denial?" 78

Referred to as 'the frankest literary work on this subject before our times', ${ }^{79}$ I would maintain that it is still relevant today owing to the strict religious moral laws that in some parts of the world still see, for example: rape victims accused of adultery, adulteresses disfigured or stoned to death, and homosexuals hanged. And lest we forget, we might also mention the sexual abuse of children by abstinent priests. Speaking of Oothoon's reference to masturbation, Paananen writes: 'Not only is masturbation the usual outcome of the sexual denial that both Blake and Oothoon oppose, but it is the physical manifestation of a society that denies relationship and commodifies the opposite sex, thereby creating the tormenting object and the private, secretive subject that Blake and Marx saw to be definitive features of bourgeois society. ${ }^{8 \circ}$ In another speech Oothoon: 'traces the connection between Christian theology and clerical privilege and the social injustices they foster, moving in quick imaginative progression from tithes to marriage as related manifestations of the same oppressive system. ${ }^{8 I}$ The speech is as follows:

77 Blake, 'To God', in Erdman, The Complete Poetry and Prose of William Blake, p. 5 I 6.

${ }^{78}$ Ryan, 'Blake and Religion', p. I 57.

79 Damon, A Blake Dictionary, p. 438.

8o Paananen, William Blake, p. 70.

8г Ryan, 'Blake and Religion', p. I 57. 
With what sense does the parson claim the labour of the farmer? Where are his nets $\&$ gins $\&$ traps. \& how does he surround him With cold floods of abstraction, and with forests of solitude, To build him castles and high spires. where kings \& priests may dwell.

Till she who burns with youth. and knows no fixed lot; is bound In spells of law to one she loathes ${ }^{82}$

In an epigraph to his poem The Four Zoas, Blake used the following statement from Paul: 'For we wrestle not against flesh and blood, but against principalities, against powers, against the rulers of the darkness of this world, against spiritual wickedness in high places. ${ }^{93}$ However, while Blake follows Paul here, in his view: 'Paul's chief error was his hostile attitude to sex that reduced it to a physical need. ${ }^{\prime 4}$ Thus Paul writes: 'It is good for a man not to touch a woman ... But if they cannot contain, let them marry, for it is better to marry than to burn. ${ }^{85}$ Whereas Blake, on the contrary, quite beautifully writes in a poem often referred to as 'Eternity': 'He who binds to himself a joy / Does the winged life destroy / But he who kisses the joy as it flies / Lives in eternity's sun rise. ${ }^{96}$

${ }^{82}$ Blake, Visions of the Daughters of Albion, Plate 5, in Erdman, The Complete Poetry and Prose of William Blake, p. 49.

83 Eph 6: I2.

${ }^{84}$ Damon, A Blake Dictionary, p. 323.

85 I Cor 7: I-9.

86 Blake, 'Eternity', in Erdman, The Complete Poetry and Prose of William Blake, p. 474. The actual extent of Blake's own sexual liberty is unknown. Ackroyd says of Blake's wife Catherine that she harboured: 'A more general discontent with her husband's opinions on sexual matters.' Ackroyd, Blake, p. 8I. Some biographers of Blake mark how he suggested having sexual relations with a concubine, which is usually understood to be one of their maids. Others suggested that the third woman was Mary Wollstonecraft. Whoever the proposed concubines were, Blake is said to have changed his mind on seeing Catherine cry in response to this suggestion. However, other biographers dismiss the third woman as no more than conjecture. Ackroyd writes: 'There is no evidence that Blake was ever unfaithful to his wife.' Ackroyd, Blake, p. 82. But James King draws attention to Alexander Gilchrist's mysterious words about Blake and Catherine: 'There had been stormy times in years long past, when both were young; discord by no means trifling while it lasted. But with the cause (jealousy on her side, not wholly unprovoked), the strife had 


\section{Transgression and the Forgiveness of Sins}

In one of his annotations, Blake remarks:

All Penal Laws court Transgression $\&$ therefore are cruelty $\&$ Murder / The laws of the Jews were (both ceremonial \& real) the basest $\&$ most oppressive of human codes $\&$ being like all other

ceased also.' James King, William Blake: His Life (London: Weidenfeld and Nicolson, I991), p. I30. Kazin says that Blake's writings show that he was: 'Tormented by her jealousy and that he thought marriage was the devil.' Kazin, The Portable Blake, p. 36. In his note book 180o-3, Blake writes: 'When a Man has married a Wife / he finds out whether / her knees \& elbows are only / glued together' Blake, in Erdman, The Complete Poetry and Prose of William Blake, p. 516. Of what he perhaps expected from a wife, Blake writes in his notes: 'In a wife I would desire / What in whores is always found / The lineaments of Gratified desire' Blake, in Erdman, The Complete Poetry and Prose of William Blake, p. 474. But perhaps the truth of the matter is contained in Blake's poem, 'My Pretty Rose Tree': 'A flower was offerd to me; / Such a flower as May never bore. / But I said I've a Pretty Rose-tree: / And I passed the sweet flower o'er. / Then I went to my Pretty Rose-tree; / To tend her by day and by night. / But my Rose turnd away with jealousy: / And her thorns were my only delight.' Blake, 'My Pretty Rose Tree', Songs of Experience, in Erdman, The Complete Poetry and Prose of William Blake, p. 25. On a lighter note, the Blake Records give the following account of Blake's liberalism in the form of his and Catherine's nudity: 'One story in particular he [Thomas Butts] was fond of telling . . . At the end of the little garden in Hercules Buildings there was a summer-house. Mr Butts calling one day found Mr. And Mrs. Blake sitting in this summer-house, freed from "those troublesome disguises" which have prevailed since the Fall. "Come in!" cried Blake; "it's only Adam and Eve, you know!" Husband and wife had been reciting passages from Paradise Lost, in character, and the garden of Hercules Buildings had to represent the Garden of Eden; a little to the scandal of wondering neighbours, on more than one occasion.' Bentley, Blake Records, pp. 53-4. For a recent discussion on what may have influenced Blake's views on sexuality, see, Craig D. Atwood, 'Christ and the Bridal Bed: Eighteenth-Century Moravian Erotic Spirituality as a Possible Influence on Blake', in Re-Envisioning Blake, Edited by, Mark Crosby, Troy Patenaude, and Angus Whitehead (Basingstoke: Palgrave Macmillan, 20I2). For example, Atwood writes: 'It is possible, and perhaps even likely, that some of the more intriguing aspects of Blake's art, poetry, and spirituality have roots in the radical religious piety his mother experienced in the Moravian Church in Fetter Lane. Eighteenth-century Moravian hymns, liturgies, and sermons are replete with sexualized imagery.' Atwood, 'Christ and the Bridal Bed', p. I6I. 
codes given under pretence of divine command were what Christ pronounced them The Abomination that maketh desolate, i.e. State Religion which is the Source of all Cruelty. ${ }^{87}$

Ryan commenting on this passage writes: 'To Blake's apocalyptic imagination the Established Church was a tool, if not an embodiment of Antichrist. ${ }^{98}$ Similarly Blake writes:

Man must \& will have Some Religion; if he has not the Religion of Jesus, he will have the Religion of Satan, \& will erect the Synagogue of Satan. calling the Prince of this World, God; and destroying all who do not worship Satan under the Name of God. Will any one say: Where are those who worship Satan under the Name of God! Where are they? Listen! Every Religion that Preaches Vengeance for Sin is the Religion of the Enemy \& Avenger; and not the Forgiver of Sin, and their God is Satan ... This was the Religion of the Pharisees who murdered Jesus. ${ }^{89}$

Elsewhere Blake tells us: 'There is a God of This World. A God Worshipd in this World as God \& set above all that is calld God.'90 For Blake then, echoing Paul in II Corinthians 4: 4, Satan is the God of this world. Satan takes possession of this world when Adam and Eve eat the fruit from the tree of knowledge of good and evil, thus bringing judgment based on moral values into the world. However, with what appears to be a Gnostic tinge Blake also understood the angry creator God of the Old Testament to be a false and cruel God. He says of this God: 'Thinking as I do that the Creator of this World is a very Cruel Being $\&$ being a

${ }_{87}$ Blake, 'Annotations to An Apology for the Bible by R. Watson, Bishop of Landaff. London, I797', in Erdman, The Complete Poetry and Prose of William Blake, p. 6I8. The term 'abomination that maketh desolate' is found in Dan 9: 27, II: 3 I and I 2: I I. See also, Ezek I I: I 8 and 2I. It is also referred to explicitly by Jesus in, Mt 24: I 5 and Mk I3: I4.

${ }^{88}$ Ryan, 'Blake and Religion', p. I 53. Note that Blake uses the term 'Antichrist' to refer to a number of things. See Damon, A Blake Dictionary, p. 25 .

89 Blake, Jerusalem, Plate 52, in Erdman, The Complete Poetry and Prose of William Blake, p. $20 \mathrm{I}$.

$9 \circ$ Blake, 'Annotations to An Apology for the Bible by R. Watson, Bishop of Landaff. London, I797', in Erdman, The Complete Poetry and Prose of William Blake, p. 618. 
Worshipper of Christ I cannot help saying the Son O how unlike the Father ... First God Almighty comes with a Thump on the Head Then Jesus Christ comes with a balm to heal it.' ${ }^{91}$ In later life Blake had stopped calling the Old Testament God 'Jehovah', and referred to the creator of the natural world as 'Elohim.' Henry Crabb Robinson discussed this notion of a false God with Blake pointing out that the Bible is the work of God, and it begins by saying that God created the heaven and earth, but Robinson then adds: 'I gained nothing by this for I was triumphantly told that this God was not Jehovah but the Elohim.'92

What does Blake mean by the difference between Jehovah and Elohim, and what is its significance? Damon (drawing on the rabbinical tradition) writes: 'Elohim (an honorific plural) is the Creator in Genesis [I]. It represents God in his aspect of Justice, as contrasted with Jehovah, the aspect of Mercy. Sometimes the word 'Elohim' should have been translated simply "judges". '93 For this reason commentators like Moses Maimonides refer to the line in Genesis 3: 5 as: 'Ye shall be as gods [judges], knowing good and evil.' The reading that refers to Adam and Eve becoming as 'judges' by eating from the tree in the midst of the garden, reinforces what Blake takes to be the Original Sin, namely, establishing oneself as a judge by dividing human realities into good and evil. Immediately after eating the fruit from the tree, Adam and Eve see they are naked and in shame cover themselves. Whereas before this they are naked and not ashamed, which literally means, not covered with clothes. For Blake then, Original Sin is to know good and evil and to judge others by moral values. Hence Adam and Eve can now see and judge, for example, their own and one another's nakedness. This is a revolutionary reading in itself owing to the fact that the distinction between good and evil is typically used to judge those who are deemed to have sinned, whereas

9r Blake, 'A Vision of the Last Judgment', in Erdman, The Complete Poetry and Prose of William Blake, p. 565.

92 Bentley, Blake Records, p. 545.

93 Damon, A Blake Dictionary, p. I I9. In his poetry and art, Blake often equates Elohim with one of the gods from his own mythology, namely, Urizen. As discussed above, Urizen symbolizes (among other things) reason and law-making. 
clearly for Blake, this judging based on the knowledge of good and evil is the actual sin. Thus, according with Jesus who crucially preached, 'Judge not', ${ }^{94}$ Blake writes: 'Who dare to Judge but God alone?'95 The knowledge of good and evil, begetting judicial and moral law, is what banishes humankind from Eden, whereas Jesus' gospel of the forgiveness of sins serves as we shall explore to reverse this.

Interestingly Blake associated the tree of the knowledge of good and evil with the gallows at Tyburn, which he called 'Albion's fatal tree.' ${ }^{96}$ The fatal fruit of this tree, what Blake also calls 'a Tree deadly and poisonous', ${ }^{97}$ allows humankind to establish itself as Elohim (gods or judges). Kazin writes: 'To him the tree in Eden is the gallows on which freedom-seeking man is hanged by deadsouled priests. ${ }^{98}$ While Jon Mee says of the gallows at Tyburn, they are: 'The place where the unity of the nation is built upon the judicial murder of some of its members. The gallows for Blake are a place where difference is suppressed so that the bogus integrity of the nation may be preserved.'99 Damon writes, for Blake: 'It is the system of Morality, the false church of Mystery, the whore of Babylon. On this tree Jesus was crucified.' ${ }^{\prime 00}$ For Blake then, Christ is crucified on the tree of the knowledge of good and evil in the midst of the garden, i.e. crucified by law and judgment.

94 Mt 7: I.

95 Blake, 'Annotations to An Apology for the Bible', in Erdman, The Complete Poetry and Prose of William Blake, p. 6I9.

${ }_{96}$ Blake, Jerusalem, Plate 82, in Erdman, The Complete Poetry and Prose of William Blake, p. 240. Damon writes: 'Tyburn was the site of the famous gallows in London. It was situated about the lower corner of Edgware Road, just to the north of Hyde Park, which was adjoined by Kensington Gardens. As the name indicates, Tyburn was near a brook, which crossed Oxford Street a little to the east of the present Marble Arch, and flowed through St. James's Park, then plunged underground at the intersection of Stratford Place and South Molton Street, which is "Calvary's foot." Elsewhere, Blake thrice associated Tyburn and Golgotha.' Damon, A Blake Dictionary, p. 4I3.

97 Blake, Jerusalem, Plate 38 , in Erdman The Complete Poetry and Prose of William Blake, p. 185.

$9^{8}$ Kazin, The Portable Blake, p. I I.

99 Jon Mee, 'Blake's Politics in History', The Cambridge Companion to William Blake (Cambridge: Cambridge University Press, 2003), p. I46.

ıo Damon, A Blake Dictionary, p. 4 Io. 
Referring to this fatal tree and seeing Albion as the punisher and judge, Blake writes:

He sat by Tyburns brook, and underneath his heel, shot up!

A deadly tree, he nam'd it Moral Virtue, and the Law

Of God who dwells in Chaos hidden from the human sight ${ }^{\text {Ior }}$

Nevertheless when it comes to his take on good and evil, Blake is ambivalent. On one level he is not looking to rid us of good and evil entirely for he saw these as fundamental to the dialectical nature of reality, which is made up of a 'dynamic interplay of opposing forces.' ${ }^{\circ 2}$ Blake called these Heraclitean forces, 'contraries.' He writes:

Without Contraries is no progression. Attraction and Repulsion, Reason and Energy, Love and Hate, are necessary to Human Existence.

From these contraries spring what the religious call Good \& Evil. Good is the passive that obeys Reason[.] Evil is the active springing from Energy.

Good is Heaven. Evil is Hell. ${ }^{103}$

Blake was wanting us to see that evil is as equally important as the good. Moreover by inverting these terms Blake appeared to see his notion of evil as the more positive aspect and good as the negative: 'Heaven and its angels, the "Good," are simply the unthinking orthodox. But Hell and its devils, the "Evil," required revaluation.' ${ }^{\circ 04}$ With reference to Milton's Paradise Lost, Blake asserts: 'The reason Milton wrote in fetters when he wrote of Angels \& God, and at liberty when of Devils \& Hell, is because he was a true poet and of the Devil's party without knowing it' ${ }^{\prime \prime o s}$

ror Blake, Jerusalem, Plate 28, in Erdman, The Complete Poetry and Prose of William Blake, p. 174.

${ }^{102}$ Marshall, William Blake: Visionary Anarchist, p. 20.

${ }^{103}$ Blake, The Marriage of Heaven and Hell, Plate 3, in Erdman, The Complete Poetry and Prose of William Blake, p. 34.

${ }^{104}$ Damon, A Blake Dictionary, p. 262.

ros Blake, The Marriage of Heaven and Hell, Plate 6, in Erdman, The Complete Poetry and Prose of William Blake, p. 35. 
In this context, Devils for Blake are the source of all creative and revolutionary energy, while Angels passively obeying reason are 'restricting spirits of conventionality.' ${ }^{\circ}{ }^{\circ}$ In this way then Blake is to a certain extent a moralist who akin to Nietzsche sought a revaluation or transposition of values.

But on another level beyond human existence, there are for Blake no moral precepts like good and evil because the forgiveness of sins preached in the Gospel cancels them out. In The Marriage of Heaven and Hell Blake writes: 'Every thing possible to be believ'd is an image of truth.' ${ }^{\text {'07 }}$ This would include the distinction between good and evil that turn humans into moralizing judges, which do not reflect how things truly are from a divine and therefore infinite viewpoint. Hence in his work Jerusalem, Blake writes:

What seems to Be: Is: To those whom

It seems to $\mathrm{Be}, \boldsymbol{Q}$ is productive of the most dreadful

Consequences to those whom it seems to Be: even of

Torments, Despair, Eternal Death; but the Divine Mercy

Steps beyond and Redeems Man in the Body of Jesus Amen

And Length Bredth Highth again Obey the Divine Vision Hallelujah. ${ }^{\text {108 }}$

For Blake, moralizing law based on a conventional or orthodox interpretation of good and evil was an error. He writes: 'And Man himself Become a Fiend, wrap'd in an endless curse, Consuming and consum'd for-ever in flames of Moral Justice. . . . Under pretence of Moral Virtue, fill'd with Revenge and Law.' ${ }^{\prime o 9}$ And we can add to this that, as far as Blake was concerned, Jesus shared the view that moralizing law was an error in that he was willing to subvert moral rules. We have quoted Blake above who said that without realizing it Milton was a true poet and so of the devil's party. Blake it has been said was the same knowingly, and

${ }^{106}$ Damon, A Blake Dictionary, p. I03.

${ }^{107}$ Blake, The Marriage of Heaven and Hell, Plate 8, in Erdman, The Complete Poetry and Prose of William Blake, p. 37.

ro8 Blake, Jerusalem, Plate 32, in Erdman, The Complete Poetry and Prose of William Blake, p. I79.

rog Blake, Jerusalem, Plate 36, in Erdman, The Complete Poetry and Prose of William Blake, p. I 82. 
so too, as he more than implies, was Jesus. ${ }^{\text {Iо }}$ Accordingly Blake held a view of Jesus diametrically opposed to that of orthodox Christianity. Blake is to his mind righting an inverted Jesus, hence he says: 'The Modern church Crucifies Christ with the Head Downwards.' ${ }^{\text {III }}$ Ryan writes:

Blake proclaimed what he understood to be the true religion of Jesus, the distinguishing qualities of which were a radical demand for social justice, the cultivation of mutual love and forgiveness, and the fostering of creative freedom in religion, morality, and the arts. The difficult mission that Blake undertook was to combat the deformed Christianity that had become the national religion of Britain, to take religion back from the priests who had subordinated it to the political, economic, and cultural agenda of the ruling classes, and to make it a truly revolutionary force in society. ${ }^{\mathrm{II} 2}$

Although, like other religions, Christianity had come to be controlled by clergy who represented and maintained the status quo, in Blake's eyes it had in truth originated with a radical visionary who had little time for either priests or conventions. For Blake, Jesus was an iconoclast who sided with artists and revolutionaries and who was about liberation rather than repression and submission. For this reason his religion of Jesus does not concern dogma, ritual, and moral lore.

When referring to Jesus' life Blake never believed in his supernatural conception, but saw him as the son of an unidentified human father, and begotten out of wedlock. ${ }^{\mathrm{II} 3}$ Related to this, and

iо Damon, A Blake Dictionary, p. Io3.

ir Blake, A Vision of the Last Judgment, in Erdman, The Complete Poetry and Prose of William Blake, p. 564.

${ }_{112}$ Ryan, 'Blake and Religion', p. I 54.

ז13 And yet according to Blake, Jesus is God owing to his claim that: 'I and my Father are one.' Jn Io: 30 , KJV. Blake saw Jesus as the 'Human God' or 'divine human', but only in the sense that he was created in God's image as indeed we all are according to Genesis I: 27. Thus Blake is said to have asserted that: 'Jesus is the only God ... And so am I and so are you.' Damon, A Blake Dictionary, p. I 58. Appearing to border on Humanism, Blake anticipating Nietzsche also writes: 'Thou art a Man God is no more, / Thy own humanity learn to adore' Blake, The Everlasting Gospel, in Erdman, The Complete Poetry and Prose of William Blake, p. 520. 
with a hint of anti-Semiticism, Blake says of his vision of Christ: 'Thine has a great hook nose like thine / Mine has a snub nose like to mine.' ${ }^{\text {II } 4}$ Likewise in his notebook he writes: 'I always thought that Jesus Christ was a Snubby or I should not have worshipd him if I thought he had been one of those long spindle nosed rascals.' ${ }^{15}$ Begotten out of wedlock, Jesus was seen from birth to be an offense against the Law. Blake believed that Jesus' mother Mary was: 'Innocently gay $\&$ thoughtless, not being among the condemned because ignorant of crime in the midst of a corrupted Age.' ${ }^{\text {Ir6 }}$ In his poem Jerusalem, Blake reads between the lines of the Gospel account that says Mary was found with child while engaged to Joseph, but before they came together; and with Joseph being a righteous man and not willing to expose her to public disgrace he was going to divorce her secretly. ${ }^{117}$ Blake creatively imagines the following conversation between Mary and her espoused Joseph:

If thou put me away from thee

Dost thou not murder me? Joseph spoke in anger \& fury. Should I Marry a Harlot \& an Adulteress? Mary answerd, Art thou more pure Than thy Maker who forgiveth Sins \& calls again Her that is Lost Tho She hates. he calls her again in love. I love my dear Joseph

But he driveth me away from his presence. yet I hear the voice of God In the voice of my Husband. tho he is angry for a moment, he will not Utterly cast me away. if I were pure, never could I taste the sweets Of the Forgive[ne]ss of Sins! if I were holy! I never could behold the tears

However, Blake's position is probably more akin to something between orthodox Deiformity and heretical Deification, for he also writes: 'God is Man \& exists in us \& we in him.' Blake, 'Annotations to Berkeley's Siris', in Erdman, The Complete Poetry and Prose of William Blake, p. 664.

${ }^{14}$ Blake, The Everlasting Gospel, in Erdman, The Complete Poetry and Prose of William Blake, p. 524.

is Blake, 'Miscellaneous Prose', in Erdman, The Complete Poetry and Prose of William Blake, p. 695.

II6 Blake, A Vision of the Last Judgment, in Erdman, The Complete Poetry and Prose of William Blake, p. 559.

I17 See Mt I; 8 -I9. 
Of love! of him who loves me in the midst of his anger in the furnace of fire. ${ }^{\text {I18 }}$

In response, Blake has Joseph weep and hold Mary in his arms. Joseph then tells Mary:

I heard his voice in my sleep \& his Angel in my dream:

Saying, Doth Jehovah Forgive a debt only on condition that it shall Be Payed? Doth he Forgive Pollution only on conditions of Purity That Debt is not Forgiven! That Pollution is not Forgiven Such is the Forgiveness of the Gods, the Moral Virtues of the Heathen, whose tender Mercies are Cruelty. But Jehovahs Salvation Is without Money $\&$ without Price, in the Continual Forgiveness of Sins,

In the Perpetual Mutual Sacrifice in Great Eternity! for behold! There is none that liveth \& Sinneth not! And this is the Covenant Of Jehovah: If you Forgive one-another, so shall Jehovah Forgive You:

That He Himself may Dwell among You. ${ }^{\text {II }}$

By reading Matthew I: $18-25$ in this way, we can see that Blake went far beyond the traditional 'Hate the sin but love the sinner.' Furthermore, when Blake writes: 'If you Forgive one-another, so shall Jehovah Forgive You: that He Himself may Dwell among you', it seems that for Blake the very act of our forgiving oneanother is simultaneously God's act of forgiving us. This puts a completely different emphasis on the following in the Lord's Prayer: 'And forgive us our debts, as we forgive our debtors.' 120 This is to say that God forgives us our debts in the very act of us forgiving our debtors. They are not distinct acts. Hence immediately after the Lord's Prayer it reads: 'For if ye forgive men their trespasses, your heavenly Father will also forgive you. But if you forgive not men their trespasses, neither will your Father forgive your trespasses. ${ }^{\text {'2I }}$ Elsewhere Blake writes: 'Where Mercy, Love \&

${ }^{118}$ Blake, Jerusalem, Plate 6o, in Erdman, The Complete Poetry and Prose of William Blake, p. 2 I I.

I19 Blake, Jerusalem, Plate 60, in Erdman, The Complete Poetry and Prose of William Blake, pp. 2 I I-I 2.

ז20 Mt 6: I2. KJV. Italics mine.

I2I Mt 6: I4-I5. KJV. 
Pity dwell, / There God is dwelling too. ${ }^{\mathrm{I} 22}$ Interpreting these lines, Hobson argues: 'God and Jesus, for Blake, are humanity, when and where it can live by these virtues.' ${ }^{\mathrm{I} 23}$ This puts into greater perspective our quoting Blake earlier as saying: 'men forgot that All deities reside in the human breast' ${ }^{124}$ and likewise: 'God only Acts \& Is, in existing beings or Men.' ${ }^{125}$

Returning to Blake's view that Mary was an adulterer, importantly this makes her a Transgressor and thus the fitting mother of Jesus who, for Blake, was the greatest of all Transgressors. ${ }^{126}$ In The Marriage of Heaven and Hell, Blake has a devil say:

If Jesus Christ is the greatest man, you ought to love him in the greatest degree; now hear how he has given his sanction to the law of ten commandments: did he not mock at the sabbath, and so mock the sabbath's God? murder those who were murderd because of him? turn away the law from the woman taken in adultery? steal the labor of others to support him? bear false witness when he omitted making a defence before Pilate? covet when he pray'd for his disciples, and when he bid them shake off the dust of their feet against such as refused to lodge them? I tell you, no virtue can exist without breaking these ten commandments: Jesus was all virtue, and acted from impulse: not from rules. ${ }^{\mathrm{I} 27}$

Similar views are expounded in Blake's unfinished poem The Everlasting Gospel, which shows that as a revolutionary fighting

${ }^{\text {I22 }}$ Blake, 'The Divine Image', Songs of Innocence, in Erdman, The Complete Poetry and Prose of William Blake, p. I3.

${ }^{123}$ Hobson, 'Anarchism and William Blake's Idea of Jesus', p. 49. Similarly, Hobson writes: 'In Jerusalem . . . the "Divine Vision" sings a song of oppression and endurance; the poem's narrator closes by saying, "This is the Song of the Lamb, sung by Slaves in evening time." Jerusalem, 60: 5 , 38. We must be careful not to assume that Blake means slaves' songs are like the divine vision; he is saying slaves' songs are the divine vision and the song of the Lamb (that is, Jesus); Jesus is slaves singing of freedom.' Hobson, 'Anarchism and William Blake's Idea of Jesus', p. 50.

${ }^{124}$ Blake, The Marriage of Heaven and Hell, Plate II, in Erdman, The Complete Poetry and Prose of William Blake, p. 38.

${ }^{125}$ Blake, The Marriage of Heaven and Hell, Plate 16, in Erdman, The Complete Poetry and Prose of William Blake, p. 40.

${ }^{126}$ Damon, A Blake Dictionary, p. 264.

${ }^{127}$ Blake, The Marriage of Heaven and Hell, Plates 22-24, in Erdman, The Complete Poetry and Prose of William Blake, p. 43. 
against the established political and religious order, Jesus is willing to defy moral principles and break the Ten Commandments. The poem therefore sets out Blake's understanding of Jesus as a transgressor of the judicial and moral law. In one fragment, Blake writes: 'The Vision of Christ that thou dost see / Is my Visions Greatest Enemy. ${ }^{128} \mathrm{He}$ also says of Christ: 'Thine loves the same world that mine hates, / Thy Heaven doors are my Hell Gates' ${ }^{\text {I29 }}$ And referring to scriptural exegesis: 'Both read the Bible day \& night, / But thou read'st black where I read white.' ${ }^{\text {I30 }}$

We cannot overlook that in the Old Testament Jehovah is responsible for a long list of deeds that can appear evil to our eyes. Thus as Damon notes Jesus' understanding of Jehovah as: 'the loving Father of all was a revolutionary concept. He was no longer the God of vengeful Justice but the God of Mercy.' '31 Elsewhere Damon says: 'The universal paternity of the all-loving Father signifies the Brotherhood of Man, the only basis for a peaceful society. But this must rest upon the freedom and development of the Individual.' ${ }^{132}$ Blake himself writes: 'What is Liberty without Universal Toleration.' ${ }^{\text {'33 }}$ Toleration then points to the 'forgiveness of sins', which Blake understood to be Jesus' revolutionary abrogation of the system of justice and punishment. ${ }^{\mathrm{I} 4}$ Thus Blake asserts: 'The Gospel is Forgiveness of Sins \& has No Moral

${ }^{\mathrm{I} 28}$ Blake, The Everlasting Gospel, in Erdman, The Complete Poetry and Prose of William Blake, p. 524.

${ }^{129}$ Blake, The Everlasting Gospel, in Erdman, The Complete Poetry and Prose of William Blake, p. 524.

r30 Blake, The Everlasting Gospel, in Erdman, The Complete Poetry and Prose of William Blake, p. 524.

${ }^{131}$ Damon, A Blake Dictionary, p. 205.

${ }^{132}$ Damon, A Blake Dictionary, p. 2I4. Hobson explores Blake's notion of Jesus as the Brotherhood of Man in some depth in his essay, 'Anarchism and William Blake's Idea of Jesus.' However, there is the danger here of an overriding tendency to see Jesus as universal humanity, and not balance this with the view that universal humanity is likewise Jesus. That is, for Blake, one cannot simply be reduced to the other.

${ }^{13} 3$ Blake, 'Annotations to Boyd's Historical Notes on Dante, Dublin, I785', in Erdman, The Complete Poetry and Prose of William Blake, p. 635.

${ }^{134}$ For Blake this was the unique insight of Jesus, and according to Damon was completely overlooked by the classical Pagan philosophers, such as, Plato and Aristotle. Damon, A Blake Dictionary, p. I4I. 
Precepts' ${ }^{35}$ Consequently, as mentioned earlier, rather than anyone establishing themselves as judges and dividing human reality into good and evil, Jesus instead asserts: 'Judge not, that ye be not judged. For with what judgment ye judge, ye shall be judged: and with what measure ye mete, it shall be measured to you again.' ${ }^{136}$

As we have seen, for Blake a significant example of the forgiveness of sins was that of Joseph forgiving Mary her alleged adultery. This is later echoed in what is perhaps the most outstanding example of the forgiveness of sins, namely, the Pericope Adulterae found in Chapter 8 of the Gospel of John. Here Jesus saves a woman (who Blake associates with Mary Magdalene) from being stoned to death in accordance with Mosaic Law for also committing adultery. Wishing to see how Jesus reacts to the law, the scribes and Pharisees ask him his view on the matter. Exposing their hypocrisy, Jesus famously replies: "He that is without sin among you, let him cast the first stone at her." ${ }^{337}$ Starting from the elders, they depart one by one until Jesus is left alone with the woman. He asks her if any man has condemned her, and when she says no, Jesus then tells her that he does not condemn her either. ${ }^{138}$

${ }^{135}$ Blake, 'Annotations to An Apology for the Bible, by R. Watson, Bishop of Landaff. London, I797', in Erdman, The Complete Poetry and Prose of William Blake, p. 619.

${ }^{136}$ Mt 7: I-2. Again Blake might read this to mean that our judging or not judging is simultaneously God's judging or not judging. Before this, Jesus questions the lex talionis, saying: 'Ye have heard that it hath been said, An eye for an eye, and a tooth for a tooth: But I say unto you, That ye resist not evil: but whosoever shall smite thee on thy right cheek, turn to him the other also.' Mt 5: 38-39, KJV. And following this says: 'Ye have heard that it hath been said, Thou shalt love thy neighbour, and hate thine enemy. But I say unto you, Love your enemies.' Mt 5: 43-44, KJV.

${ }^{137}$ Jn 8: 7, KJV.

${ }^{138}$ It is interesting to note that during this exchange with the scribes and Pharisees, Jesus bends down twice to write in the ground with his finger. Nothing is said about this in the text, but it may be a reference to the following in Jeremiah: 'O LORD, the hope of Israel, all that forsake thee shall be ashamed, and they that depart from me shall be written in the earth, because they have forsaken the LORD, the fountain of living waters.' Jer I 7: I3, KJV. Tradition has it that Jesus is actually writing out the sins of the scribes and Pharisees after asking them to cast a stone if they are without sin. I also wonder if Jesus is writing in the ground to show 
Jesus often questions and denounces the scribes and Pharisees for being advocates of a narrow legalism who, without purity of soul, outwardly comply with conventional morality: 'Woe unto you, scribes and Pharisees, hypocrites! For ye are like unto whited sepulchres, which indeed appear beautiful outward, but are within full of dead men's bones, and of all uncleanness.' ${ }^{\mathrm{I} 39}$ In The Everlasting Gospel, Blake says of the Pericope Adulterae:

Was Jesus Chaste or did he

Give any Lessons of Chastity

The morning blushd fiery red

Mary was found in Adulterous bed

Earth groand beneath \& Heaven above

Trembled at discovery of Love

Jesus was sitting in Moses Chair

They brought the trembling Woman There

Moses commands she be stoned to Death

What was the sound of Jesus breath

He laid His hand on Moses Law

The Ancient Heavens in Silent Awe

Writ with Curses from Pole to Pole

All away began to roll ${ }^{140}$

Blake then has Jesus say to the scribes and Pharisees:

... Come Ye forth

Fallen Friends of Heavnly birth

That have forgot your Ancient love

And driven away my trembling Dove

You shall bow before her feet

that the spirit of the law is not engraved in stone tablets as is the letter of the law.

${ }^{139}$ Mt 23: 27, KJV.

${ }^{14} \circ$ Blake, The Everlasting Gospel, in Erdman, The Complete Poetry and Prose of William Blake, p. 521. Beer writes: 'The Jesus revealed in this poem is someone who does not adhere slavishly to the law but who interprets experience in a more humane manner, understanding that the adulterous woman has at least the virtue of living by love. Other passages show him failing to fulfil any suggestions that he showed humility - or even gentility - so far as relations with his fellows were concerned.' Beer, William Blake: A Literary Life, p. I 88. 
You shall lick the dust for Meat

And tho you cannot Love but Hate

Shall be beggars at Loves Gate ${ }^{\mathrm{T} 4 \mathrm{I}}$

Finally, Blake says of Jesus:

The Publicans \& Harlots he

Selected for his Company,

And from the Adulteress turn'd away

God's righteous Law, that lost its Prey. ${ }^{142}$

E. P. Thompson says of Blake: 'In shedding the prohibitives of the Moral Law; Blake held fast to the affirmative: Thou Shalt Love. It is because this affirmative remains an essential need and quest of our own times that William Blake still speaks with such power to us. ${ }^{\mathrm{I} 43}$ Accordingly Blake asserts:

Mutual in one anothers love and wrath all renewing

We live as One Man; for contracting our infinite senses

We behold multitude; or expanding: we behold as one,

As One Man all the Universal Family; and that One Man

We call Jesus the Christ: and he in us, and we in him,

Live in perfect harmony in Eden the land of life,

Giving, receiving, and forgiving each others trespasses. ${ }^{\text {I44 }}$

By a continual forgiving of each other's trespasses, Hobson points to Blake's belief in human imperfection, which, he argues, is paradoxically the key to Blake's idea of nonauthoritarian society. If we recall, we quoted Blake as saying: 'There is none that liveth $\&$ Sinneth not!' 145 The notion of perfectibility is said to be deeply entrenched in radical thought. The argument is that because people

${ }^{{ }^{4} \mathrm{I}}$ Blake, The Everlasting Gospel, in Erdman, The Complete Poetry and Prose of William Blake, p. 522.

${ }^{142}$ Blake, The Everlasting Gospel, in Keynes, Blake: Complete Writings (London: Oxford University Press, I966), p. 757. Note that this passage does not appear in Erdman's text.

${ }^{143}$ E. P. Thompson, Witness Against the Beast: William Blake and the Moral Law (Cambridge: Cambridge University Press, I993), p. I28.

${ }^{144}$ Blake, Jerusalem, Plate 34, in Erdman, The Complete Poetry and Prose of William Blake, p. I80.

${ }^{145}$ Blake, Jerusalem, Plate 6I, in Erdman, The Complete Poetry and Prose of William Blake, p. 2 I 2. 
are not perfect they need to be shaped from above by a more perfect leadership. ${ }^{\mathrm{I} 6}$ Hence communism can soon become totalitarianism. Blake was aware of such regimes from England's religious history (Cromwell, for example), and witnessed it in his own life with the French Revolution that replaced one form of tyranny with another. Hobson writes:

In place of the French "republic of Virtue", which led to vesting supreme power in virtue's guardians, Blake offered the idea of continual forgiveness of sins ... By implication, if there is continual forgiveness of sin, the ideological justification for a hierarchy of social guardians vanishes, a crucial step in convincing people to abolish the hierarchies in reality.' ${ }^{\mathrm{I} 47}$

We noted above that the only basis for a peaceful society rests upon the freedom and thus development of the individual. Blake writes: 'The worship of God is. Honouring his gifts in other men'148 Appearing to echo Jesus' command to: 'Love your enemies' ${ }^{\text {'49, }}$ Blake insightfully and quite beautifully suggests that: 'Opposition is true Friendship.' ${ }^{50}$ This is not to my mind a simple call to 'live and let live', but more subtly and profoundly says, 'let live and live.' For as Blake affirms: 'Mutual Forgiveness of each Vice / Such are the Gates of Paradise' ${ }^{15 \mathrm{I}}$ This is to say that through the mutual forgiveness of those that trespass against one another liberty is granted to each in the process. Consequently all life is increased in

\footnotetext{
${ }^{\text {I46 }}$ Hobson, 'Anarchism and William Blake's Idea of Jesus', p. 53.

${ }^{147}$ Hobson, 'Anarchism and William Blake's Idea of Jesus', p. 53.

${ }^{148}$ Blake, The Marriage of Heaven and Hell, Plate 22, in Erdman, The Complete Poetry and Prose of William Blake, p. 43.

I49 See Mt 5: 44 .

15० Blake, The Marriage of Heaven and Hell, Plate 20, in Erdman, The Complete Poetry and Prose of William Blake, p. 42. Incidentally, this line of Blake's brings to mind the following passage from Pierre Teilhard de Chardin: 'In any domain - whether it be the cells of a body, the members of a society or the elements of a spiritual synthesis - union differentiates. In every organised whole, the parts perfect themselves and fulfil themselves.' Teilhard de Chardin, The Phenomenon of Man, (London: Collins, I955), p. 40.

${ }^{15}$ Blake, For the Sexes: The Gates of Paradise, in Erdman, The Complete Poetry and Prose of William Blake, p. 259.
} 
recognition that: 'Every thing that lives is Holy' ${ }^{\text {I52 }}$ Paradoxically, it seems that tolerated difference through forgiveness not only brings about liberation for all, but also allows for a more genuine harmony, which, as we saw above, equates for Blake with Eden the land of life. It also equates with Jerusalem, which as the Holy City of Peace always represents 'liberty' for Blake. This perhaps gives renewed emphasis to Blake's famous lines:

I will not cease from Mental Fight,

Nor shall my Sword sleep in my hand:

Till we have built Jerusalem,

In Englands green \& pleasant Land. ${ }^{153}$

While I have referred above to society resting upon the liberty and development of the individual, we must be careful here and stress that Blake's anarchism does not simply serve to promote individual choice and thus freedom. This is more a means than an end. Blake's vision is not about the individual self and certainly does not advocate what we might call a subjective or private take on religion. Blake's vision is radically social. The love between people is a mutual love made 'in the Perpetual Mutual Sacrifice in Great Eternity!' 54 It is through the forgiveness of sins that we become a Universal Humanity or Divine Body living as One Man Jesus Christ. As Blake says: 'General Forms have their vitality in Particulars: \& every particular is a Man; a Divine Member of the Divine Jesus.' ${ }^{155}$ And elsewhere: 'The Eternal Body of Man is THE IMAGINATION. God himself / that is / The Divine Body ... [Yeshua] JESUS we are his Members. ${ }^{156}$ These citations almost certainly appear to echo Paul when he says: 'Now ye are the Body

${ }^{152}$ Blake, The Marriage of Heaven and Hell, Plate 27, in Erdman, The Complete Poetry and Prose of William Blake, p. 45.

${ }^{153}$ Blake, Milton, in Erdman, The Complete Poetry and Prose of William Blake, pp. 95-6.

${ }^{154}$ Blake, Jerusalem, Plate 6I, in Erdman, The Complete Poetry and Prose of William Blake, p. 2 I 2.

${ }^{155}$ Blake, Jerusalem, Plate 9I, in Erdman, The Complete Poetry and Prose of William Blake, p. $25 \mathrm{I}$.

${ }^{156}$ Blake, Laocoön, in Erdman, The Complete Poetry and Prose of William Blake, p. 273. 
of Christ, and members in particular.' ${ }^{\text {I57 }}$ There also appears to be a trace of Paul's reference to God being, 'all in all.' ${ }^{58}$ Likewise Paul's description of the true Christ who: 'is before all things, and by him all things consist.' ${ }^{159}$ And there are clearly parallels with Jesus when he says: 'Again I say unto you, That if two of you shall agree on earth as touching any thing that they shall ask, it shall be done for them of my Father which is in Heaven. For where two or three are gathered together in my name, there I am in the midst of them. ${ }^{\text {' } 60}$

Another crucial point to consider is that the mutual forgiveness of sins should not be taken as another moral law or divine command used to bind people in terms of 'thou shalt.' And of course there is the added danger that this warning in the form of should not is also taken as yet another prescriptive demand to counter the initial danger. These are indeed dangers that miss the point and rightly court transgression. The doctrine of forgiveness (if it is a doctrine) must stem from self-sacrifice and love. To rule by judicial or moral law that you must, for example, tolerate does not bring about toleration. It becomes yet another moral code used to enslave and judge people. Blake's advocacy of love and forgiveness represents God in His aspect of Mercy - not Justice. A genuine forgiveness of sins repeals moral precepts. It

${ }_{157}$ I Cor I 2: 27. KJV.

${ }^{158}$ I Cor I 5. 28, KJV.

${ }_{59} \mathrm{Col}$ I: I7, KJV. Another figure who was greatly influenced by Paul was Teilhard de Chardin, and Blake's Divine Body of Christ consisting of particular members is akin to Teilhard's Cosmic Christ. Throughout his work Teilhard argues that 'union differentiates', which is to say that in any organized whole the parts become more autonomous not less so and form a harmonized complexity rather than becoming lost in the great whole. For example, he writes: 'Now, what is the only way in which a centre can be formed and sustained as such? Is it by breaking down the lower centres which fall under its governance? Indeed it is not - it is by strengthening them in its own image. Pierre Teilhard de Chardin, Christianity and Evolution (Orlando, Florida: Harcourt Brace and Company, I969), p. II7.

${ }^{160} \mathrm{Mt}$ I 8: I9-20. KJV. I am indebted in this paragraph to the essay, 'William Blake and Life in the Divine Body', by Christopher Rowland in, Paul, Grace, and Freedom: Essays in Honour of John K. Riches, edited by, Paul Middleton, Angus Paddison, and Karen Wenell (London and New York: T \& T Clark International, 2009), pp. I I9-I30. 
is a case of putting love before the letter of the law, as we saw with the woman taken in adultery. Through mutual forgiveness Jesus is among us as us, that is 'he in us, and we in him.' ${ }^{\text {I6I }}$ Thus mutual forgiveness mirrors Paul's call for unity indicating: 'One God and Father of all, who is above all, and through all, and in you all.' ${ }^{\text {'62 }}$

A significant question, I believe, emerges when we ask how Blake's view of Jesus as a transgressor of rabbinical law squares with the following words attributed to him: 'Think not that I come to destroy the law, or the prophets: I am not come to destroy, but to fulfil.' ${ }^{163}$ It is argued that selections of the sayings of Jesus were in circulation before the Gospels were produced, and some were preferred by stricter Jewish Christians: 'Such a selection of sayings could be drawn up in accordance with the outlook of those who compiled it; sayings which in themselves appeared to support that outlook would be included, while others which appeared to go contrary would be omitted.' ${ }^{\text {'64 }}$ Matthew is said to have not limited himself to one selection. However the source said to draw from 'a more legally minded Christian circle' ${ }^{165}$ is often labelled $\mathrm{M}$ because it only features in Matthew's Gospel, while a more comprehensive selection is referred to as Q. An example here is the verse that follows the one just quoted, which has Jesus say: 'For verily I say unto you, Till heaven and earth pass, one jot or one tittle shall in no wise pass from the law, till all be fulfilled.' ${ }^{166}$ The scholar T. W. Manson argued that coming from the $\mathrm{M}$ form this was a revision of the original wording designed to bring it in line with rabbinical doctrine. Whereas Luke's version of the saying, 'It is easier for heaven and earth to pass, than one tittle of the law to fail' ${ }^{167}$ came from the $\mathrm{Q}$ form and was closer to the original. Furthermore Manson argues that: 'The saying in

${ }^{161}$ Blake, Jerusalem, Plate 34, in Erdman, The Complete Poetry and Prose of William Blake, p. I80.

${ }_{162}$ Eph 4: 6, KJV.

${ }_{163}$ Mt 5: I7, KJV.

${ }^{164}$ Walter C. Kaiser Jr., and, Peter H. Davids, F. F. Bruce, Manfred T. Brauch, Hard Sayings of the Bible (Illinois, IVP Academic, I996), p. 355.

${ }^{165}$ Kaiser, et al., Hard Sayings of the Bible, p. 355.

${ }^{166}$ Mt 5: I 8, KJV.

ז67 Lk I6: I7, KJV. 
its original form asserts not the perpetuity of the Law but the unbending conservatism of the scribes' and is not meant to be 'sound Rabbinical dogma but bitter irony.' ${ }^{\prime 68}$ Thus interpreted correctly Manson understands Jesus to be saying to the scribes: 'The world will come to an end before you give up the tiniest part of your traditional interpretation of the law.' ${ }^{\text {I69 }}$

It is apparent that Jesus did not adhere to the rabbinical interpretation of the law. And when the scribes and Pharisees accuse his disciples of transgressing the tradition of their elders by not washing their hands before eating bread, Jesus replies: 'Why do ye also transgress the commandment of God by your tradition?' Yet crucially, and surely Blake would have agreed, for Jesus circumstances could alter cases in that (taking an obvious example): 'The sabbath was made for man, and not man for the sabbath.' ${ }^{17 \mathrm{I}}$ But Jesus does not ignore the necessities of God's law nor encourage his followers to be less just, as the ensuing verse confirms: 'That except your righteousness exceed the righteousness of the scribes and Pharisees, ye shall in no case enter in the kingdom of heaven.' ${ }^{172}$ When he is left alone with the woman taken in adultery and it is confirmed that no man including himself condemns her, Jesus does not simply tell her to go, but rather to go 'and sin no more.' ${ }^{173}$ But crucially this I would argue is not to be seen as a condition for forgiveness. We quoted Blake earlier as saying:

Doth Jehovah Forgive a debt only on condition that it shall Be Payed? Doth he Forgive Pollution only on conditions of Purity

${ }_{168}$ T. W. Manson, The Sayings of Jesus (Reprint; Grand Rapids, Mich.: Eerdmans, I979), p. I35.

${ }^{6} 69$ Manson, The Sayings of Jesus, p. I 35.

${ }_{170}$ Mt I 5: 3, KJV.

${ }^{17 \mathrm{I}} \mathrm{Mk}$ 2: 27, KJV.

${ }^{172}$ Mt 5: 20, KJV. From another point of view Jesus' fulfils the law which he sees as the expression of God's will because obeying or disobeying the law begins in the heart. He constantly called the scribes and Pharisees hypocrites because they only followed the law outwardly and not inwardly. Jesus' mind and will is to do the will of God and: 'where this is so, there will be an emphasis on the inward spiritual aspects of ethics and religion, rather than on outward and material aspects.' Kaiser, et al., Hard Sayings of the Bible, p. 357.

${ }^{173}$ Jn 8: I I, KJV. 
That Debt is not Forgiven! That Pollution is not Forgiven Such is the Forgiveness of the Gods, the Moral Virtues of the Heathen, whose tender Mercies are Cruelty. But Jehovah's Salvation

Is without Money \& without Price, in the Continual Forgiveness of $\operatorname{Sins}^{174}$

Yet significantly Blake goes one step further and has Mary add to her sin of adultery the sin of blaspheming Love and Jesus. In so doing he twists the notion of what it is to sin. For Mary her added sin occurred because she concealed her true nature, and so speaking to Jesus she refers to her:

Dark pretence to Chastity

Blaspheming Love blaspheming thee

Thence Rose Secret Adulteries

And thence did Covet also rise

My Sin thou hast forgiven me

Canst thou forgive my Blaspehemy ${ }^{175}$

In Blake's interpretation of Joseph forgiving Mary her alleged adultery it would seem that in line with the rabbinical tradition, Elohim as Justice and Jehovah as Mercy are correlated as Elohim Jehovah. This is because for Blake, as we touched upon earlier, Elohim as Justice and Jehovah as Mercy are necessary to each other in that sin can only be forgiven when it is first judged to be $\sin .{ }^{176}$ For Blake: 'Justice, the punishment of (or vengeance for) $\sin$... was the Contrary of Mercy, the forgiveness of sin. It was the Old Dispensation of Moses, annulled by the New Dispensation of Jesus.' ${ }^{177}$ And perhaps this New Dispensation is precisely how Jesus, in Blake's view, fulfils the law.

${ }^{174}$ Blake, Jerusalem, Plate 60, in Erdman, The Complete Poetry and Prose of William Blake, p. 2 I 2.

${ }^{175}$ Blake, The Everlasting Gospel, in Erdman, The Complete Poetry and Prose of William Blake, p. 522.

${ }^{176}$ Damon, A Blake Dictionary, p. I 19.

${ }^{177}$ Damon, A Blake Dictionary, p. 227. 


\section{Conclusion}

I have tried to show that to a certain extent Blake can be understood as an anarchist in that he advocated all forms of liberation and rebelled against all authority - State and King, Church and God, Master and Mammon, Parent and Teacher. However I have not referred to Blake simply as an anarchist, but as a Christian anarchist. The advocacy of liberation from authority was for him best expressed in what he deemed to be the true spirit of Christianity, namely, Jesus' subversion of all judicial and moral law. And so while Blake was arguably a heretic among the orthodox, he was nevertheless a Christian in his anarchism in that among political radicals he staunchly defended what he saw as the true religion of Jesus and thus true spirit of Christianity. Accordingly he attacked religion that was a law and a tye to minds, but always asserted that the religion of Jesus was a perfect law of liberty. ${ }^{178}$

Yet we have seen that Blake was also an anarchist in his Christianity. For Blake the views of Jesus were diametrically opposed to the orthodox views of the Church in that Jesus had little respect for priests, laws or conventions. Arguably Blake sought to do battle with a distorted Christianity and make it a revolutionary force in society by taking it back from the priests who had subordinated it to the political, economic and cultural agendas of the ruling classes. ${ }^{179} \mathrm{He}$ mistrusted institutional state religion, which for him was the source of all cruelty, and attacked its priests for binding believers with law. Blake saw Jesus as a transgressor of law through his insight into the mutual forgiveness of sins, which repealed the system of justice and punishment. We saw that for Blake law is not a remedy for social disorder and moral chaos, but one of its principal causes. ${ }^{180}$ In Blake's view human ills are not due to our transgressing divine law but because of the loss of imagination to restrictive reason, and our unwillingness to cultivate human energies in freedom. ${ }^{\mathrm{I} 8 \mathrm{I}} \mathrm{He}$ wanted individuals to be free to cultivate their own mind and imagination, and to become

\footnotetext{
${ }^{178}$ See Ackroyd, Blake, p. I 59.

179 See Ryan, 'Blake and Religion', p. I 54.

ı80 See Marshall, William Blake: Visionary Anarchist, p. 42.

18. See Beer, William Blake: A Literary Life, p. 97.
} 
king, priest and artist in their own home. ${ }^{182}$ Radically inverting our notion of good and evil, Blake understood that the good who passively obey reason are the unthinking orthodox and restricting spirits of conventionality. ${ }^{183}$ While the evil are those who actively follow the creative and revolutionary energies that reason always seeks to circumscribe and limit. In Blake's eyes it appears that the latter is represented best by true artists and poets who are never fettered, but like Jesus seek to pursue and advocate the revolutionary liberty that constitutes the true spirit of religion. Through his own artistic freedom and religious spirit Blake it seems sought to undo institutionalised Christianity, which he felt perverted Jesus' original anarchistic message of love and liberty.

But does all I have discussed above make Blake a Christian anarchist? I noted in the introduction that understanding Blake as a Christian anarchist is different from saying that he identified himself as one. For me Blake is only a Christian anarchist by implication. Christian anarchism, either as a movement or a concept, is not something he consciously identified with and subscribed to. The scope of this essay has made it easier to view Blake as a Christian anarchist by drawing relevant samples of his writing together that fit this description. But I think we should be cautious here, while nevertheless acknowledging Blake's tacit Christian anarchist tendencies. It is not my intention then to thoughtlessly claim that Blake was a Christian anarchist in the strictest sense of the term. Blake is tautologically Blake to such an extent that categorising him as anything other than Blake is a mistake in my view. And given his temperament, even this is a box he would have likely wished to leap out of. Consequently, he refuses to be pinned down and claimed for any particular cause. ${ }^{184}$ Beer says: 'No doubt there were shifts in Blake's attitudes, corresponding to the dominant tone of the work he was producing at any given time, but his personality cannot be contained within any single one of them. ${ }^{1{ }^{18} 5}$ Similarly Ackroyd argues: 'Blake did not join clubs or circles and, for similar reason of temperament, he rarely

\footnotetext{
${ }^{182}$ Marshall, William Blake: Visionary Anarchist, p. 9.

${ }_{183}$ See Damon, A Blake Dictionary, p. I03 and p. 262.

${ }^{184}$ See Beer, 2007, p. 24.

${ }^{185}$ Beer, 2007 , p. 36.
} 
became attached to ideas or suggestions other than those that he formulated for himself. But he was immensely receptive to beliefs which might confirm his own sense of life.' ${ }^{186}$

Tellingly, Blake has his god Los say in the poem Jerusalem: 'I must Create a System or be enslav'd by another Man's. ${ }^{187}$ A little further Blake refers to Los: 'Striving with Systems to deliver Individuals from those Systems.' ${ }^{188}$ While P. H. Butter adds that Los must also: 'Create new systems so as not to be enslaved by his own.' ${ }^{89}$ I think these three positions evince Blake's character and serve to indicate how he was indeed anarchistic. It is this utter spirit of liberty guided by his religious vision that is perhaps testament to his Christian anarchism - to the extent that he fits such a label precisely by escaping it.

This last remark may intrigue and yet tantalise. It announces a paradoxical relationship between Blake's work and anarchist positions. What is this paradox? What is it in anarchist thought that Blake's work resonates with, and in what sense does his work escape that dimension? It is themes evident in his work, such as, 'dissent', 'radicalism', 'revolution', 'antinomianism', 'transgression', and 'liberty', that indirectly characterise anarchism and thus associate him with anarchistic thought.

Yet Blake was too much of an anarchist to be labelled an anarchist. Just as a genuine existentialist might escape the label 'existentialist' on the grounds of authenticity, so Blake might elude the title 'anarchist' on the grounds of liberty. His spirited temperament, complex character, and visionary imagination prevent his strict conformity to any type. In short, he was one of a kind. Thus any type used beside his name has to conform as much to him. A category, even the category 'anarchist', defines and so sets limits like the circumscribing compass of Urizen. And, as we saw, Blake is loath to step into any such circles. It is this unrestrained and

${ }_{186}$ Ackroyd, I995, p. 88.

187 Blake, Jerusalem, Plate ıo, in Erdman, The Complete Poetry and Prose of William Blake, p. I 53. Los is a god in Blake's pantheon, and represents the poetic spirit in humankind.

I88 Blake, Jerusalem, Plate I I, in Erdman, The Complete Poetry and Prose of William Blake, p. I 54.

I89 P. H. Butter, William Blake: Selected Poems (London: J. M. Dent \& Sons, I982), p. xxvii. 
boundless liberty that, for me, characterises his anarchism, an anarchism given its central focus on Jesus that we might cautiously call a Christian anarchism.

\section{References}

Ackroyd, Peter, Blake (London: Sinclair-Stevenson, I995)

Beer, William Blake: A Literary Life (Basingstoke: Palgrave Macmillan, 2007)

Bentley, Jr., G. E., ed., Blake Records (Oxford: Clarendon Press, I969)

Bulfinch, Thomas, Bulfinch's Mythology (London: Spring Books, I967)

Butter, P, H, ed., William Blake: Selected Poems (London: J. M. Dent and Sons, I982)

Crosby, Mark, with Troy Patenaude, and Angus Whitehead, eds., ReEnvisioning Blake (Basingstoke: Palgrave Macmillan, 20I 2)

Damon, S. Foster, A Blake Dictionary (Hanover and London: University Press of New England, I988)

Damon, S. Foster, William Blake: His Philosophy and Symbols (Whitefish, Montana: Kessinger Publishing, 2006)

Eaves, Morris, The Cambridge Companion to William Blake (Cambridge: Cambridge University Press, 2003)

Erdman, David, V., The Complete Poetry and Prose of William Blake (New York: Anchor Books, I988)

Gilchrist, Alexander, Life of William Blake, ed. Ruthven Todd (London and New York, 1942)

Hobson, 'Anarchism and William Blake's Idea of Jesus', The Utopian, Vol. I, (2000)

Holmes, Richard, Blake's Songs of Innocence and of Experience (London: Tate Publishing, I99I)

Kaiser, Jr., Walter C., and, Peter H. Davids, F. F. Bruce, Manfred T. Brauch, Hard Sayings of the Bible (Illinois: IVP Academic, I996)

Kazin, Alfred, The Portable Blake (Harmondsworth: Penguin Books, I946) 
Keynes, Geoffrey, (Ed.), Blake: Complete Writings (London: Oxford University Press, I966)

King, James, William Blake: His Life (London: Weidenfeld and Nicolson, I99I)

Manson, T. W., The Sayings of Jesus (Reprint; Grand Rapids, Mich.: Eerdmans, I979)

Marshall, Peter, William Blake: Visionary Anarchist (London: Freedom Books, I988)

Middleton, Paul, with Angus Paddison and Karen Wenell, (Eds.), Paul, Grace, and Freedom: Essays in Honour of John K. Riches (London and New York: T \& T Clark International, 2009)

Milton, John, The Annotated Milton: Complete English Poems, (Ed.), Burton Raffel (New York: Bantam Books, I999)

Nietzsche, Friedrich, Thus Spoke Zarathustra, (Tr.), R. J. Hollingdale (London: Penguin, 196I)

Nietzsche, Friedrich, Twilight of the Idols, (Tr.), R. J. Hollingdale (London: Penguin, I968)

Nietzsche, Friedrich, Beyond Good and Evil, (Tr.), R. J. Hollingdale (London: Penguin, I973)

Paananen, Victor, N, William Blake (New York: Twayne Publishers, I996)

Shelley, Percy Bysshe, The Poetical Works of Shelley (London: Oxford University Press, 1905)

Strong, James, Strong's Exhaustive Concordance of the Bible (Peabody, Massachusetts: Hendrickson Publishers, 2007)

Teilhard de Chardin, Pierre, Christianity and Evolution (Orlando, Florida: Harcourt Brace and Company, I969)

Teilhard de Chardin, Pierre, The Phenomenon of Man (London: Collins, I955)

Thompson, E, P, Witness Against the Beast (Cambridge University Press, I993) 